\title{
Antioxidant characteristics of non-traditional spicy- aromatic vegetable raw materials for restaurant technology
}

\section{Oleksandr Khareba ${ }^{1}$, Oleg Kuzmin ${ }^{2}$, Olena Khareba ${ }^{1}$, Victor Marynchenko², Margaryta Karputina ${ }^{2}$, Iryna Koretska²}

\author{
1 - National University of Life and Environmental sciences of Ukraine, Kyiv, Ukraine \\ 2 - National University of Food Technologies, Kyiv, Ukraine
}

Keywords:

Spicy-aromatic

Vegetable

Antioxidant

Redox

Restaurant

Article history:

Received 21.09.2020

Received in revised

form 11.12.2020

Accepted

30.06.2021

Corresponding

author:

Oleg Kuzmin

E-mail:

kuzmin_ovl@ukr.net

DOI:

$10.24263 / 2304-$

974X-2021-10-2-8

\section{Abstract}

Introduction. The aim of the study is to determine the antioxidant capacity of non-traditional for restaurant technology spicy-aromatic vegetable raw materials.

Materials and methods. Antioxidant capacity of spicyaromatic plant raw materials: Hyssopus officinalis L., Dracocephalum moldavica L., Agastache foeniculum L., Melissa officinalis L., Ocimum basilicum L., Foeniculum vulgare Mill., Glebionis coronaria L., Satureja hortensis L. were determined by redoxmetry and pH-metry of water-alcohol infusions; sensory indicators - by expert method; the results of mathematical and statistical processing - by the method of linear Pearson correlation.

Results and discussion. The hydrogen index for water-alcohol infusions from spicy-aromatic raw materials has a value of 5.28 units $\mathrm{pH}$ (Hyssopus officinalis L.) to 6.69 units $\mathrm{pH}$ (Agastache foeniculum $L$.). The minimum theoretical value of redox potential $(R P)$ for plant water-alcohol infusions, which varies from $258.6 \mathrm{mV}$ (Agastache foeniculum L.) to $343.2 \mathrm{mV}$ (Hyssopus officinalis L.), was obtained. The actual measured $R P$ of infusions was established - from $93 \mathrm{mV}$ (Hyssopus officinalis L.) to $148 \mathrm{mV}$ (Glebionis coronaria $L$.). Water-alcohol infusions from plant raw materials and a volume fraction of ethanol of $40 \%$ have a value of reduction energy $(R E)$ in the range from $120.6 \mathrm{mV}$ (Agastache foeniculum L.) to $250.2 \mathrm{mV}$ (Hyssopus officinalis L.). Water-alcohol infusions from spicy-aromatic raw materials have values of sensory evaluation (S.e.) from 9.50 to 9.68 points. The greatest value of S.e. - 9.68 points characteristic of Melissa officinalis L.: color - light brown; taste - moderately burning, grassy; aroma - herbal, lemon.

The use of spicy-aromatic vegetable raw materials for restaurant technology is promising. Studies have confirmed the biological value of aromatic herbs for enriching tea and herbal compositions, white and red basic sauces, compotes and improving sensory evaluation.

Conclusion. The use of spicy-aromatic vegetable raw materials from Hyssopus officinalis L. and Melissa officinalis L., which received increased antioxidant characteristics $R E-250.2 \mathrm{mV}$ and $R E-184.6 \mathrm{mV}$, respectively, and positive sensory evaluation S.e. -9.53 and S.e. -9.68 points. 


\section{Introduction}

Currently, the use of vegetable raw materials (Andreou et al., 2018; Belemets et al., 2016; Chandrasekara, Shahidi, 2018; Fotakis et al., 2016; Halliwell, Gutteridge, 1990; Hrabovska et al., 2015, 2018; Iannitti, Palmieri, 2009; Kawa-Rygielska et al., 2019; Kochubei-Lytvynenko et al., 2017) in restaurant business is very relevant (Gnytsevych et al., 2018; Gubskyi et al., 2015; Deinychenko et al., 2020; Ianchyk et al., 2016, 2018; Niemirich et al., 2015-2017; Sylchuk et al., 2016, 2017).

Current demand for high-quality spicy-aromatic vegetable raw materials involves the development of new technological methods for its preparation, with increased quality control, environmental friendliness, higher energy efficiency, lower cost and safer operation (Dainelli et al., 2008; Mujumdar, Law, 2010). These methods will allow to preserve biologically active substances (Swasdisevi et al., 2009) - volatile aromatic substances, phenolic compounds, reduce their losses (Ruan et al., 2021; Pavlyuk et al., 2018), increase organoleptic properties (Mayor, Sereno, 2004).

These biologically active substances are very sensitive to the conditions of preparation, especially to solvents - water (Tülek et al., 2020), ethyl alcohol, water-alcohol mixture (Kuzmin et al., 2020). Therefore, the conditions necessary for the efficient extraction of these compounds are specific to each plant, and this is an important issue in the process of their extraction (Tülek et al., 2020). Despite some achievements, a number of issues remain related to the preparation of spicy-aromatic plant raw materials (Priecina et al., 2018), which has antioxidant capacity. These are rare plant crops in Ukraine that are unconventional for restaurant technology (Kuzmin et al., 2020).

Spicily-aromatic vegetable raw materials contain different chemical substances that display a broad spectrum of biological activities (Frolova et al., 2019; Gerolis et al., 2017; Imark et al., 2000; Kamdem et al., 2013; Pyrzynska, Sentkowska, 2019; Sentkowska, Pyrzynska, 2018; Siddiqui et al., 2018; Steenkamp et al., 2004; Wong et al., 2020).

They have gained growing interest among scientists and consumers due to their antioxidant properties (Breiter et al., 2011; Dube et al., 2017. The ability of plant phenolics to act as free radical scavengers has led to increased interest in their ability to act as antioxidants (Herrera et al., 2018; Humia et al., 2020; Keating et al., 2014; Oh et al., 2013). Antioxidants are able to reduce the output of oxidation products: hydroperoxides, alcohols, aldehydes, ketones, fatty acids.

Spicy-aromatic raw material that exhibits antioxidant and tonic properties (Kurylo et al., 2018; Vergun et al., 2018; Vergun et al., 2019). At present, the antioxidant characteristics of all prescription components, food additives, biologically active substances and their combinations have not been sufficiently studied (Buglass et al., 2012; Grunert et al., 2018; Gullón et al., 2018; Gulua et al., 2018; Joubert, Beer, 2012).

These circumstances determine the relevance of this work, which is to develop wateralcohol extracts of vegetable raw materials in the technology of restaurants. Creating restaurant products with reduced toxicity through the introduction of spicy-aromatic infusions with antioxidant properties, allows restaurant establishments to create new products, which favorably differentiates them from competitors, creating a favorable image of the institution, which cares for the protection of consumers.

The aim of the study is to determine the antioxidant capacity of non-traditional for restaurant technology spicy-aromatic vegetable raw materials.

To achieve this goal, the following research objectives were set:

- To confirm the prospect of using non-traditional for restaurant technology spicyaromatic vegetable raw materials; 
- To establish the value of antioxidant capacity of spicy-aromatic vegetable raw materials;

- To carry out the mathematical and statistical analysis of indicators of antioxidant ability of spicy-aromatic vegetable raw materials and to establish internal correlation;

- To identify the richest sources of natural antioxidants due to spicy-aromatic plant raw materials for use in restaurant technology;

- To investigate the compositions of spicy-aromatic vegetable raw materials for restaurant technology.

\section{Materials and methods}

\section{Materials}

The study used plant raw materials that are allowed to be used in the production of restaurant products. In the M.M. Gryshko National Botanic Garden of NAS of Ukraine was created new cultures of spicy-aromatic plants, which became the subject of these studies (Rakhmetov, 2011).

The studies used spicy aromatic vegetable raw materials: Hyssopus officinalis L.; Dracocephalum moldavica L.; Agastache foeniculum L.; Melissa officinalis L.; Ocimum basilicum L.; Foeniculum vulgare Mill.; Glebionis coronaria L.; Satureja hortensis L. For preparation of extracts used the following basic raw materials: ethanol rectified, water, cardboard filtering.

\section{Description of research procedure}

Drying of spicy-aromatic vegetable raw materials was carried out in natural conditions for 6-8 days to constant humidity - not more than $14 \%$. Collected and inspected raw materials were laid out on clean white paper, each type separately.

The first stage - the preparation of infusions. Plant raw materials were minced into a size of $3 \times 3 \mathrm{~mm}$, suspensions of $4 \mathrm{~g}$ were placed into the glass bottles, were filled by $100 \mathrm{ml}$ of alcohol solvent with volume fraction of rectified ethyl alcohol $40 \%$. The resulting infusions were cooled to $20^{\circ} \mathrm{C}$ for 7 days, stirring periodically.

Next, the infusions were filtered and studies were performed to determine the indicators of active acidity, which was measured on a $\mathrm{pH}$ meter in the mode of $\mathrm{pH}$ measurement with a combined glass electrode. The $R P$ was measured in the potential measurement mode with a combined redoxmetric platinum electrode.

\section{Description of methods}

\section{Expert method of sensory evaluation}

The expert method of determination of values of indexes of quality is based on the account of opinions of group highly skilled specialists-experts. (The expert of - it a specialist on the certain type of object which owns the increased sensitiveness to properties of this object) (Kuzmin et al., 2016). 


\section{Methods for determining antioxidant capacity}

$R P$ is an important indicator of the biological activity of solutions (Kuzmin O. et al., 2016; Merwe et al., 2017). It characterizes the deviation from the ionic balance of free electrons in a liquid medium. Changing the concentration of free electrons leads to a change in its electron charge and, accordingly, the $R P$. If the $R P$ is positive, it indicates the oxidizing ability of the solution, negative indicates recovery ability. The value of $R P$ allows to estimate the energy of processes, that is, characterizes the activity of ions in redox reactions (Bahir, 1999; Priluckij, 1997). Therefore, in order for the human body to optimally use in the exchange processes water-alcohol solutions and food, the $R P$ values must correspond to the $R P$ values of the internal environment of the organism, or have more negative values (Bahir, 1999).

To evaluate the antioxidant properties of the obtained water-alcoholic plant extracts, the method (Priluckij, 1997), based on the difference of $R P$ in inactivated inorganic solutions and complex biochemical media. The main criteria of this method were its clarity, simplicity, specificity, reproducibility of results and efficiency. A number of researchers also emphasize that method allows to determine the total antioxidant activity of liquid products, including in total in a complex mixture, and multifunctional antioxidants (Kuzmin et al., 2016).

Formula (1) holds for inactivated inorganic solutions in equilibrium. This formula links the active acidity of the $p H$ and the $R P$ (Priluckij, 1997):

$$
E h_{\min }=660-60 \cdot p H, \mathrm{mV}
$$

where $E h_{\min }$ - the minimum theoretically expected value of the $R P$;

$p H-$ active acidity of the test solution.

Acquired $R P$ values were compared with actual measurements of $E h_{\text {act }}$ solution. The change of the $R P$ toward the recovery energy $(R E)$ was determined by the formula (Priluckij, 1997):

$$
R E=E h_{\text {min }}-E h_{\text {act }}, \mathrm{mV}
$$

where $R E$ - the shift of $R P$ to the side of recovered meanings (resilence);

$E h_{\min }-$ minimal theoretically expected meaning of $R P$;

$E h_{\text {act }}$ - actual measured $R P$.

\section{Mathematical and statistical methods}

Pearson correlation coefficient measures the strength of the linear association between variables. Each variable should be continuous, random sample and approximately normally distributed. There are many rules of thumb on how to interpret a correlation coefficient, but all of them are domain specific. For example, here is correlation coefficient (Table 1) interpretation for behavioral sciences offered by Hinkle et al., 2003.

The correlation coefficient can take a range of values from +1 to -1 . Positive correlation coefficient means that if one variable gets bigger, the other variable also gets bigger, so they tend to move in the same direction. Negative correlation coefficient means that the variables tend to move in the opposite directions: If one variable increases, the other variable decreases, and vice-versa. When correlation coefficient is close to zero two variables have no linear relationship (Hinkle et al., 2003; Shendrik et al., 2019). 
Correlation coefficient interpretation

Table 1

\begin{tabular}{|c|c|}
\hline Absolute value of coefficient $(\boldsymbol{r})$ & Strength of correlation \\
\hline $0.90-1.00$ & Very high \\
\hline $0.70-0.90$ & High \\
\hline $0.50-0.70$ & Moderate \\
\hline $0.30-0.50$ & Low \\
\hline $0.00-0.30$ & Little, if any \\
\hline
\end{tabular}

\section{Results and discussions}

\section{Sensory evaluation}

The results of sensory evaluation (S.e., points) of the obtained infusions on the extractant are presented in the Table 2 and Figures 1.

\section{Quality indicators of extracts on extractant}

Table 2

\begin{tabular}{|l|c|c|c|c|c|c|}
\hline \multicolumn{1}{|c|}{ Plant raw materials } & $\boldsymbol{t}^{\mathbf{0}} \mathbf{C}$ & $\boldsymbol{p H}$ & $\begin{array}{c}\boldsymbol{E} \boldsymbol{h}_{\mathbf{m i n}}, \\
\mathbf{m V}\end{array}$ & $\begin{array}{c}\boldsymbol{E} \boldsymbol{h}_{\text {act, }} \\
\mathbf{m V}\end{array}$ & $\begin{array}{c}\boldsymbol{R} \boldsymbol{E}, \\
\mathbf{m V}\end{array}$ & $\begin{array}{c}\text { S.e. } \\
\text { points }\end{array}$ \\
\hline 1. Hyssopus officinalis L. & 20 & 5.28 & 343.2 & 93 & 250.2 & 9.53 \\
\hline 2. Dracocephalum moldavica L. & 19 & 6.14 & 291.6 & 113 & 178.6 & 9.57 \\
\hline 3. Agastache foeniculum L. & 18 & 6.69 & 258.6 & 138 & 120.6 & 9.65 \\
\hline 4. Melissa officinalis L. & 18 & 6.09 & 294.6 & 110 & 184.6 & 9.68 \\
\hline 5. Ocimum basilicum L. & 19 & 6.22 & 286.8 & 105 & 181.8 & 9.62 \\
\hline 6. Foeniculum vulgare Mill. & 18 & 6.51 & 269.4 & 115 & 154.4 & 9.50 \\
\hline 7. Glebionis coronaria L. & 19 & 6.38 & 277.2 & 148 & 129.2 & 9.51 \\
\hline 8. Satureja hortensis L. & 19 & 6.03 & 298.2 & 108 & 190.2 & 9.63 \\
\hline 9. Extractant - water-alcohol mixture & 19 & 7.96 & 182.4 & 180 & 2.4 & 9.57 \\
\hline min & $\mathbf{1 8}$ & $\mathbf{5 . 2 8}$ & $\mathbf{2 5 8 . 6}$ & $\mathbf{9 3}$ & $\mathbf{1 2 0 . 6}$ & $\mathbf{9 . 5 0}$ \\
\hline max & $\mathbf{2 0}$ & $\mathbf{6 . 6 9}$ & $\mathbf{3 4 3 . 2}$ & $\mathbf{1 4 8}$ & $\mathbf{2 5 0 . 2}$ & $\mathbf{9 . 6 8}$ \\
\hline
\end{tabular}

where: $t$ - temperature of infusion; $p H$ - active acidity of the test solution;

$E h_{\min }-$ minimal theoretically expected meaning of $R P ; E h_{a c t}-$ actual measured $R P$;

$R E$ - recovery energy; S.e. - sensory evaluation of extracts

\section{Antioxidant capacity}

Physicochemical studies, namely determination of the $p H$ level and $R P$ (Nicoli et al., 2004; Prévost, Brillet-Viel, 2014), were performed according to the method (Priluckij, 1997) and calculations given above (Kuzmin et al., 2016). As a result of extraction received infusions (Andreou et al., 2018; Chandrasekara, Shahidi, 2018; Halliwell, Gutteridge, 1990; Iannitti, Palmieri, 2009; Kawa-Rygielska et al., 2019), physicochemical indicators (Breiter et al., 2011; Dube et al., 2017) of which are presented in the Table 2. 


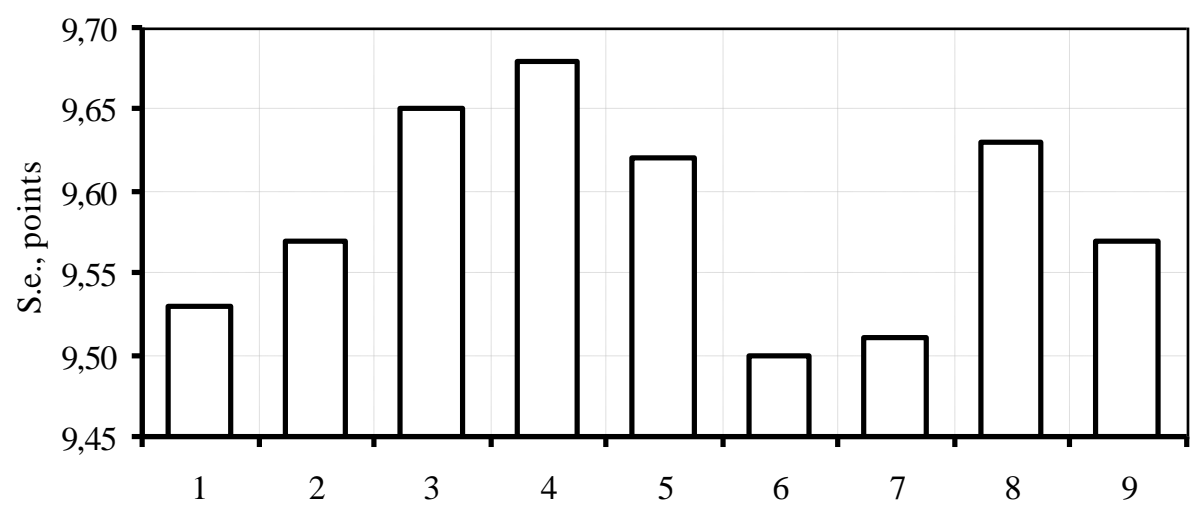

Figure 1. Sensory evaluation indicators of extracts on the extractant:

1 - Hyssopus officinalis L.; 2 - Dracocephalum moldavica L.; 3 - Agastache foeniculum L.; 4 -Melissa officinalis L.; 5 - Ocimum basilicum L.; 6 - Foeniculum vulgare Mill.;

7 - Glebionis coronaria L.; 8-Satureja hortensis L.; 9 - Extractant-water-alcohol mixture

Figures 2-5 show graphically the change in the physicochemical indicators of the quality of extracts of spicy-aromatic raw materials on the extractant.

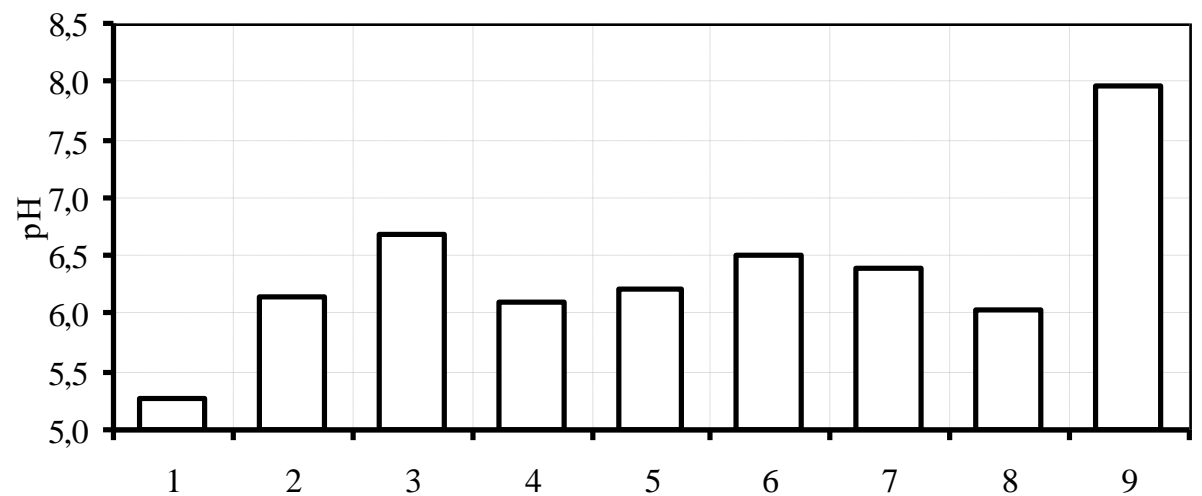

Figure 2. Hydrogen index ( $p H$ ) of infusions of the investigated raw material:

1 - Hyssopus officinalis L.; 2 -Dracocephalum moldavica L.; 3 -Agastache foeniculum L.;

4 -Melissa officinalis L.; 5 -Ocimum basilicum L.; 6-Foeniculum vulgare Mill.;

7 -Glebionis coronaria L.; 8-Satureja hortensis L.; 9 -Extractant-water-alcohol mixture

The minimum theoretical value of $R P\left(E h_{\min }\right)$ for plant water-alcohol infusions (Priluckij, 1997) was obtained, which has a value from $258.6 \mathrm{mV}$ (Agastache foeniculum L.) to 343.2 $\mathrm{mV}$ (Hyssopus officinalis L.). The actual measured $R P$ of infusions $\left(E h_{a c t}\right)$ was established from $93 \mathrm{mV}$ (Agastache foeniculum L.) to $148 \mathrm{mV}$ (Glebionis coronaria L.). The hydrogen index for water-alcohol infusions from spicy-aromatic raw materials has a value of 5.28 units pH (Hyssopus officinalis L.) to 6.69 units pH (Agastache foeniculum L.). 


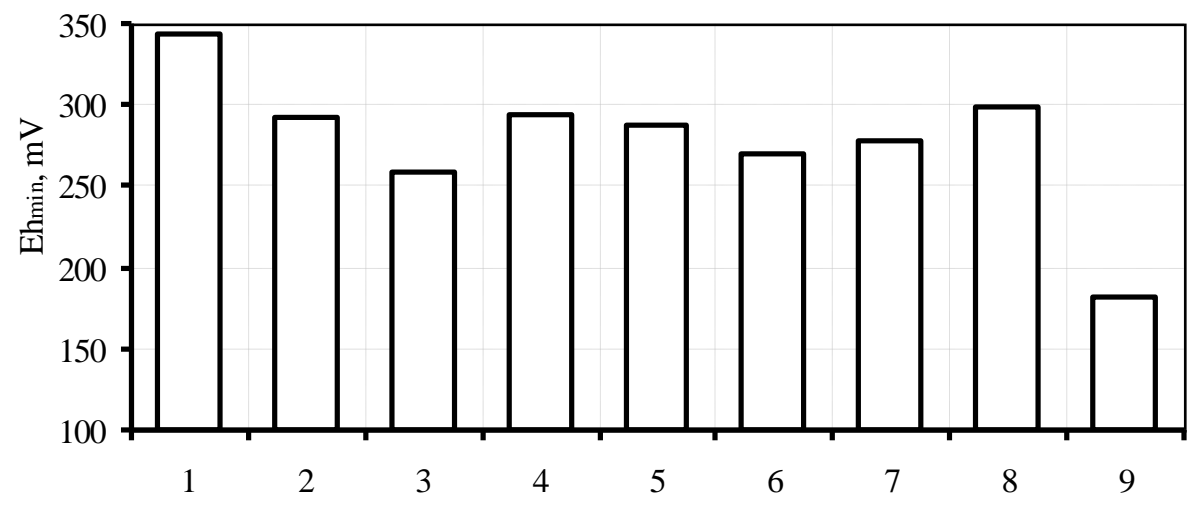

Figure 3. The minimum theoretical value of $R P\left(E h_{\min }\right)$ of infusions of the investigated raw material:

1 - Hyssopus officinalis L.; 2 - Dracocephalum moldavica L.; 3 - Agastache foeniculum L.; 4 -Melissa officinalis L.; 5 - Ocimum basilicum L.; 6 - Foeniculum vulgare Mill.;

7 - Glebionis coronaria L.; 8-Satureja hortensis L.; 9 - Extractant-water-alcohol mixture

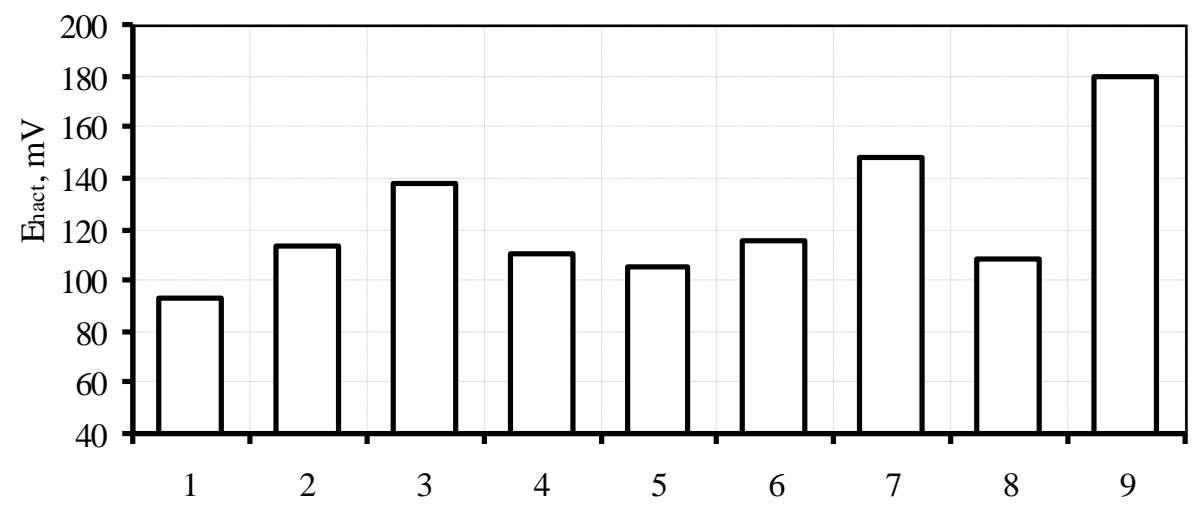

Figure 4. The actual measured $R P$ of infusions $\left(E h_{a c t}\right)$ of infusions of the investigated raw material:

1 - Hyssopus officinalis L.; 2 - Dracocephalum moldavica L.; 3 - Agastache foeniculum L.; 4 -Melissa officinalis L.; 5 - Ocimum basilicum L.; 6 - Foeniculum vulgare Mill.;

7 - Glebionis coronaria L.; 8 -Satureja hortensis L.; 9 - Extractant-water-alcohol mixture

Water-alcohol infusions from vegetable raw materials and a volume fraction of ethanol of $40 \%$ have the value of regenerative capacity (recovery energy $-R E$ ) in the range from $R E$ - $120.6 \mathrm{mV}$ (Agastache foeniculum L.) to RE - $250.2 \mathrm{mV}$ (Hyssopus officinalis L.). For the restaurant business in the manufacture of beverages are promising water-alcohol infusions of Hyssopus officinalis L. and Melissa officinalis L., which received increased antioxidant characteristics $R E-250.2 \mathrm{mV}$ and $R E-184.6 \mathrm{mV}$, respectively, and positive sensory 
evaluation (S.e.) -9.53 and S.e. -9.68 points.

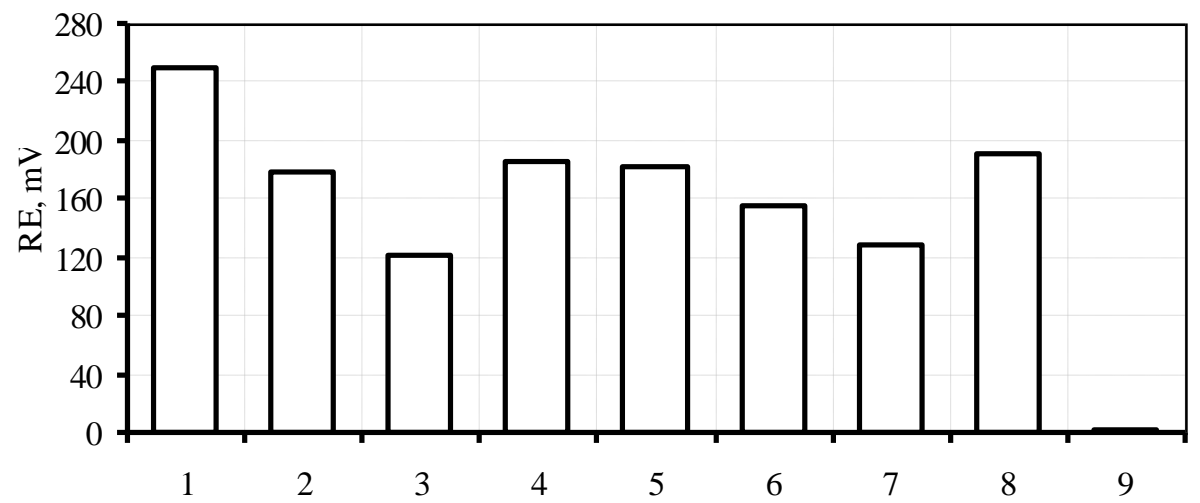

Figure 5. Recovery energy (RE) of infusions of the investigated raw material:

1 - Hyssopus officinalis L.; 2 -Dracocephalum moldavica L.; 3 -Agastache foeniculum L.; 4 -

Melissa officinalis L.; 5 - Ocimum basilicum L.; 6 - Foeniculum vulgare Mill.; 7 - Glebionis coronaria L.; 8 -Satureja hortensis L.; 9 -Extractant-water-alcohol mixture

The prescription composition of alcoholic beverages may include water-alcohol infusions.

\section{Determination of Pearson's linear correlation}

According to the physicochemical and sensory evaluation, mathematical and statistical analysis (Hinkle et al., 2003; Shendrik et al., 2019) was performed in the Pearson correlation matrix (Table 3).

Marked correlations $(r)$ are significant at $p<0,05 ; N=9$

Table 3

\begin{tabular}{|l|c|c|c|c|c|c|}
\hline & $\boldsymbol{t}$ & $\boldsymbol{p H}$ & $\boldsymbol{E h}_{\min }$ & $\boldsymbol{E h}_{\text {act }}$ & $\boldsymbol{R E}$ & S.e. \\
\hline$t$ & 1.00 & -0.3 & 0.3 & -0.16 & 0.27 & -0.38 \\
\hline$p H$ & -0.33 & 1.0 & $\mathbf{- 1 . 0}$ & $\mathbf{0 . 9 1}$ & $\mathbf{- 0 . 9 9}$ & 0.00 \\
\hline$E h_{\min }$ & 0.33 & $\mathbf{- 1 . 0}$ & 1.0 & $\mathbf{- 0 . 9 1}$ & $\mathbf{0 . 9 9}$ & -0.00 \\
\hline$E h_{\text {act }}$ & -0.16 & $\mathbf{0 . 9}$ & $\mathbf{- 0 . 9}$ & 1.00 & $\mathbf{- 0 . 9 6}$ & -0.13 \\
\hline$R E$ & 0.27 & $\mathbf{- 1 . 0}$ & $\mathbf{1 . 0}$ & $\mathbf{- 0 . 9 6}$ & 1.00 & 0.05 \\
\hline$S . e$. & -0.38 & 0.0 & -0.0 & -0.13 & 0.05 & 1.00 \\
\hline
\end{tabular}

where: $t$ - temperature of infusion; $p H$ - active acidity of the test solution; $E h_{\min }$ - minimal theoretically expected meaning of $R P ; E h_{a c t}$ - actual measured $R P$; $R E$ - recovery energy; S.e. - sensory evaluation

According to the obtained matrix $6 * 6$, it was found that of the 6 indicators $\left(t, p H, E h_{\min }\right.$, $E_{\text {hact }}, R E$, S.e.), only 4 indicators are statistically significant. As a result of research it was 
found that physicochemical parameters $\left(t, p H, E h_{\text {min }}, E h_{a c t}, R E\right)$ are statistically insignificant for sensory evaluation (S.e.), because the correlation coefficient is very weak $(r 0.0-0.3)$ and weak $(r 0.3-0.5)$. Also, a weak $(r 0.3-0.5)$ and very weak $(r 0.0-0.3)$ relationship is observed between temperature $(t)$ and other physicochemical and sensory evaluation. The range of values with very high correlation $(r 0.9-1.0)$ includes the following indicators: $p H, E h_{\min }$, $E_{\text {hact }}, R E$.

Figure 6 shows the graphical dependence of $p H$ on $E h_{\min }$. It was found that the $p H$ is in the range of 5.28-7.96, and $E h_{\min }-182.4-343.2 \mathrm{mV}$. According to the obtained equation, at a $p H$ value of $6.00 E h_{\min }$ is $300 \mathrm{mV}$. When the $p H$ value changes by 1 ( $\left.p H 7.00\right)$, the $E h_{\min }$ decreases by $60 \mathrm{mV}\left(E h_{\min } 240 \mathrm{mV}\right)$. That is, the relationship between $E h_{\min }$ and $p H$ is very high, because $r=-1$, because it is inversely correlated, which leads to an increase in $p H$ to a decrease in the level of $E h_{\min }$.

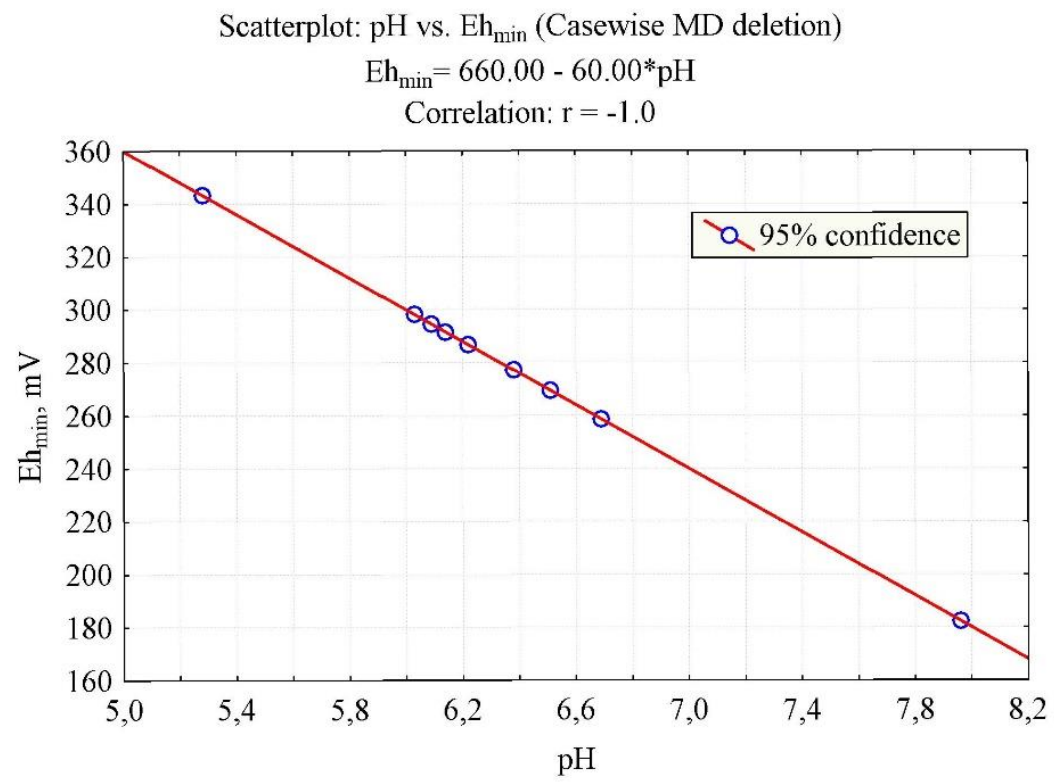

Figure 6. Dependence of $p H$ level on the $R P\left(E h_{\text {min }}\right)$

Figures 7-11 show the graphical dependence of the $p H$ level, $E h_{a c t}, E h_{\min }, R E$.

It was found that $E h_{a c t}$ is in the range from 93 to $180 \mathrm{mV}$, and the $p H$ is $5.28-7.96$. At the value of $E h_{\text {act }} 111 \mathrm{mV}$, the $p H$ level is 6.0. If you increase the $p H$ to by one to 7.0 then the value of $E h_{\text {act }}$ will be $145 \mathrm{mV}$, i.e. $E h_{\text {act }}$ will increase by $34 \mathrm{mV}$. This is due to the fact that there is a very strong interdependence between the variables $E h_{a c t}$ and $p H(r=0.9)$. As the $p H$ value increases, the $E h_{a c t}$ index increases.

It was found that $R E$ is in the range from 2.4 to $250.2 \mathrm{mV}$, and the $p H$ is $5.28-7.96$. When the value of $R E 190 \mathrm{mV}$, the $p H$ level is 6.0. If you increase the $p H$ by one to 7.0, the value of $R E$ will be $95 \mathrm{mV}$. Increasing the $p H$ per unit from 6.0 to 7.0 leads to a decrease in $R E$ by $94 \mathrm{mV}$. This is due to the fact that there is a very strong interdependence between the variables $R E$ and $p H(r=-1.0)$. As the $p H$ value increases, the $R E$ decreases.

The general graph of the three most correlation-significant physicochemical parameters is shown in Figure 12. In volumetric form, it is seen that some points $\left(E h_{a c t}, R E, E h_{\min }\right)$ are as close as possible to the surface, i.e. there is a very strong correlation between them. The 


\section{— Food Technology}

farther the points are from the surface, the weaker the relationship.

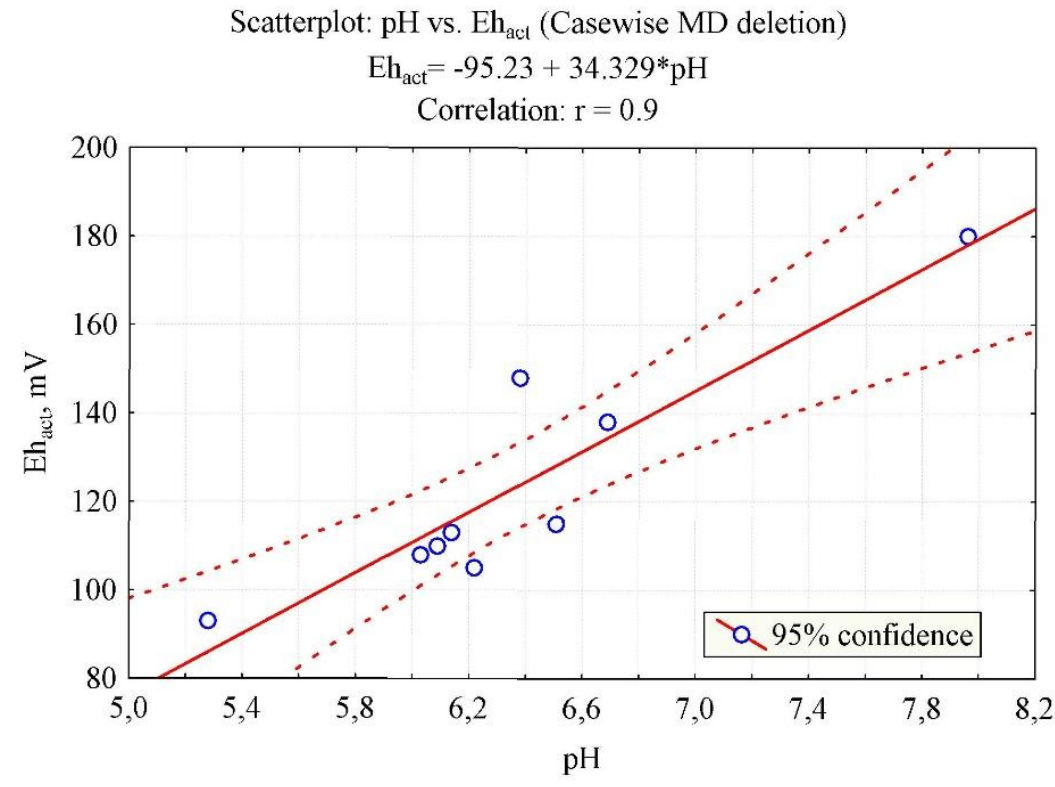

Figure 7. Dependence of $p H$ level on the $R P\left(E h_{a c t}\right)$

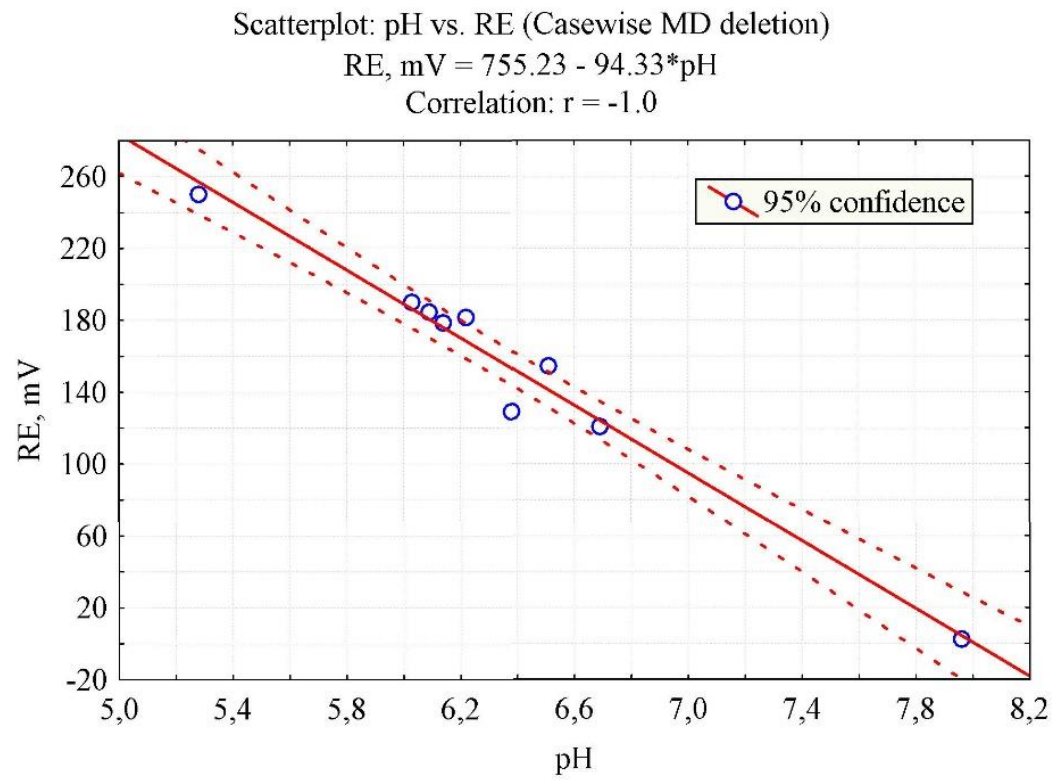

Figure 8. Dependence of $p H$ level on reduction energy $(R E)$ 
Scatterplot: $E h_{\min }$ vs. $E h_{\text {act }}$ (Casewise MD deletion)

$$
\mathrm{Eh}_{\mathrm{act}}=282.39-0.5722 * \mathrm{Eh}_{\min }
$$

Correlation: $r=-0.9$

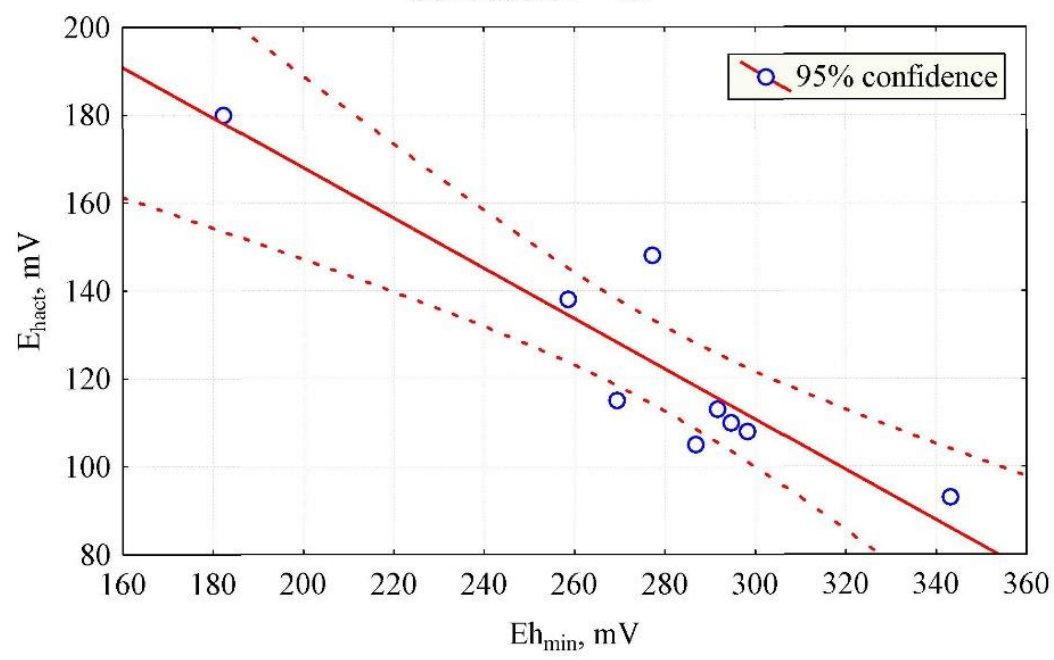

Figure 9. Dependence of $R P\left(E h_{m i n}\right)$ on $R P\left(E h_{a c t}\right)$

Scatterplot: $\mathrm{Eh}_{\min }$ vs. RE (Casewise MD deletion)

$\mathrm{RE}=-282.4+1.5722 * \mathrm{Eh}_{\text {min }}$

Correlation: $\mathrm{r}=1.0$

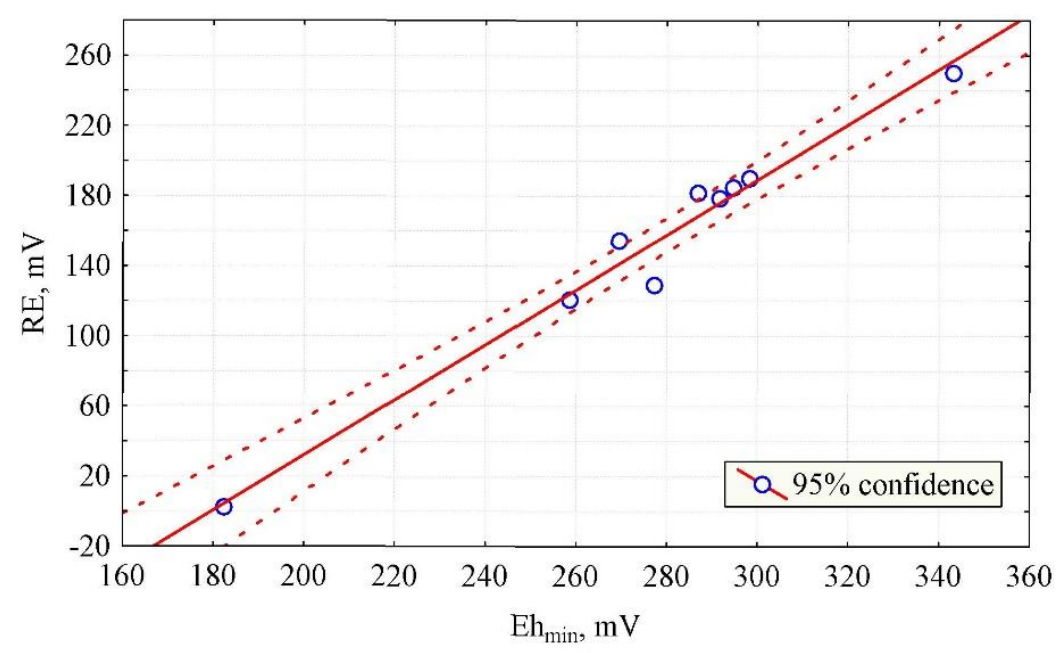

Figure 10. Dependence of $R P\left(E h_{\text {min }}\right)$ on reduction energy $(R E)$ 
Scatterplot: $\mathrm{Eh}_{\text {act }}$ vs. RE (Casewise MD deletion)

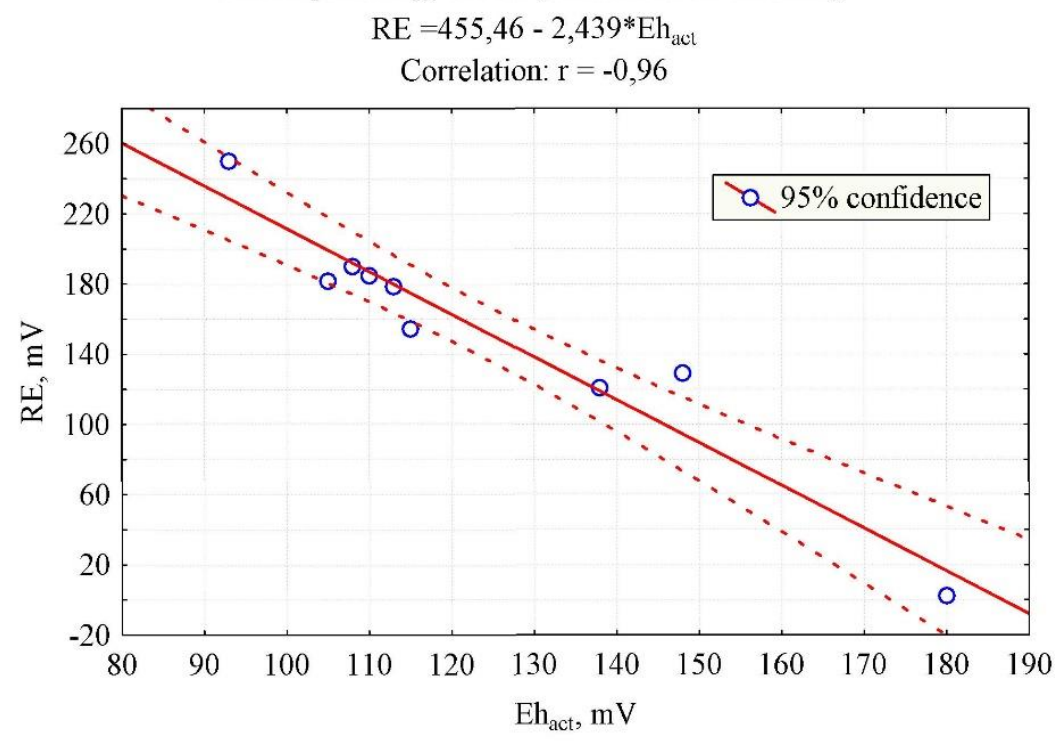

Figure 11. Dependence of $R P\left(E h_{a c t}\right)$ on reduction energy $(R E)$

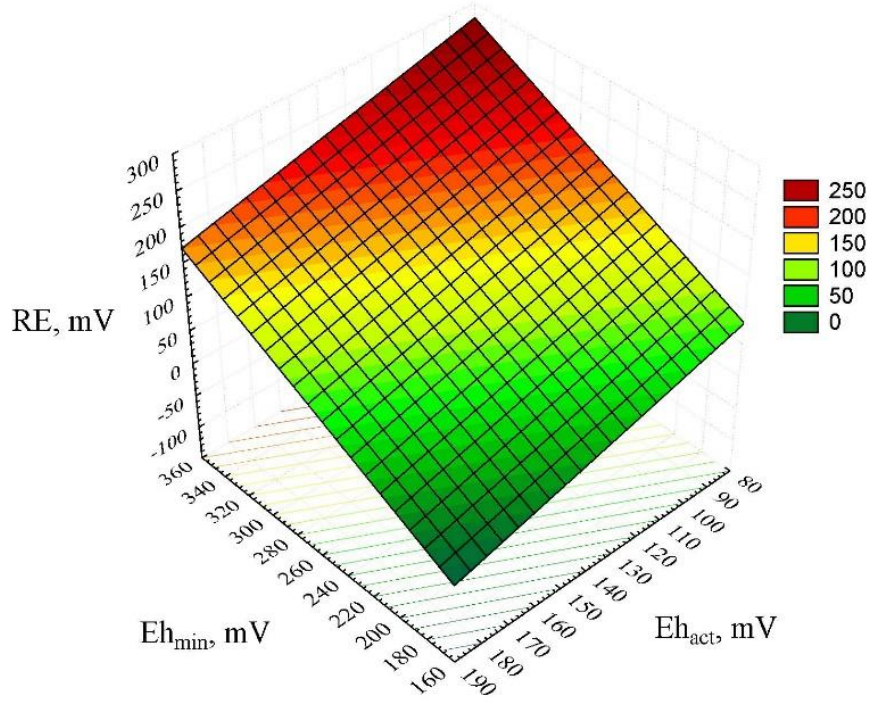

Figure 12. Response surface of $R P\left(E h_{a c t}\right)$ from reduction energy $(R E)$ and $R P\left(E h_{\text {min }}\right)$ 
Based on mathematical and statistical analysis, it was found that physicochemical parameters $\left(p H, E h_{\min }, E h_{a c t}, R E\right)$ are statistically insignificant for sensory evaluation (S.e.) and infusion temperature $(t)$. The range of values with very high correlation $(r 0.9-1.0)$ includes the following indicators: $p H, E h_{\min }, E h_{a c t}, R E$.

Sensory evaluation of tea-herbal compositions with the addition of spicy-aromatic vegetable raw materials

The results of sensory evaluation of tea-herbal compositions are shown in table 4 .

Sensory evaluation of tea-herbal compositions

Table 4

\begin{tabular}{|c|c|c|c|c|c|}
\hline Compositions & 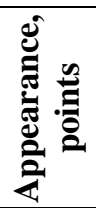 & 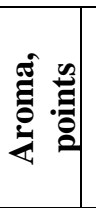 & 产 & 苞 & نَّ \\
\hline Long black tea & 5.0 & 5.0 & 4.9 & 4.8 & 4.925 \\
\hline Melissa officinalis $L$. & 5.0 & 5.0 & 5.0 & 4.9 & 4.975 \\
\hline Satureja hortensis L. & 4.9 & 4.8 & 4.6 & 4.6 & 4.725 \\
\hline Agastache foeniculum $L$. & 5.0 & 5.0 & 4.9 & 4.9 & 4.950 \\
\hline Melissa officinalis L. + Satureja hortensis L. & 4.9 & 4.9 & 4.9 & 4.7 & 4.850 \\
\hline Melissa officinalis L. + Agastache & 5.0 & 5.0 & 5.0 & 4.9 & 4.975 \\
\hline $\begin{array}{l}\text { Melissa officinalis L. + Hyssopus officinalis } \\
\text { L. + Dracocephalum moldavica L. }\end{array}$ & 5.0 & 5.0 & 4.9 & 4.6 & 4.875 \\
\hline $\begin{array}{l}\text { Melissa officinalis } L .+ \text { Agastache foeniculum } \\
\text { L. }+ \text { Hyssopus officinalis } L .+ \\
\text { Dracocephalum moldavica } L .\end{array}$ & 5.0 & 5.0 & 4.7 & 4.9 & 4.900 \\
\hline
\end{tabular}

The highest score was obtained by tea-herbal compositions based on Melissa officinalis L. and a mixture of Melissa officinalis L. + Agastache foeniculum L. (1:1) - S.e. 4.975 points. The prospects of creating tea-herbal compositions based on ready-made dried mixtures have been confirmed by many authors (Alaşalvar, Çam, 2019; Tülek et al., 2020).

\section{Sensory evaluation of white main sauce with the addition of spicy-aromatic vegetable raw materials}

Evaluation of spicy-aromatic plants in mixtures showed that unsurpassed in taste, aroma and overall tasting evaluation of white main sauce based on meat broth with the addition of spicy spices (bay leaf, black peas, ground black pepper) and experimental samples of plants (broth) from beef + bay leaf + black pepper peas + ground black pepper + greens + Hyssopus officinalis L. + Ocimum basilicum L. + Dracocephalum moldavica L.) (Table 5).

The undoubted advantage of non-traditional for restaurant spicy-aromatic vegetable raw materials is its biological value. The presence in the composition of substances that have antimicrobial, antioxidant, hepatoprotective properties, improve digestion when used daily in small doses. They do not cause allergies, have a positive effect on the psychophysical state of man. Studies have confirmed the value and availability of spicy-aromatic vegetable raw materials to culinary dishes and can be successfully used instead of the traditional set of spices or supplement them. 
Table 5

Sensory evaluation of white main sauce

\begin{tabular}{|c|c|c|c|c|c|}
\hline Compositions & 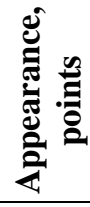 & 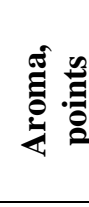 & 产 & 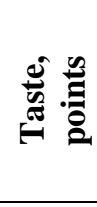 & ن் \\
\hline White sauce (main) on beef broth (control) & 5.0 & 5.0 & 4.8 & 4.6 & 4.850 \\
\hline $\begin{array}{l}\text { White sauce }+ \text { bay leaf }+ \text { black pepper peas }+ \\
\text { ground black pepper }+ \text { greens }\end{array}$ & 5.0 & 5.0 & 4.8 & 5.0 & 4.950 \\
\hline White sauce + Hyssopus officinalis $L$ & 4.6 & 4.6 & 4.2 & 4.1 & 4.375 \\
\hline White sauce + Ocimum basilicum $L$. & 4.9 & 5.0 & 4.6 & 4.6 & 4.775 \\
\hline White sauce + Dracocephalum moldavica $L$. & 5.0 & 4.8 & 4.3 & 4.3 & 4.600 \\
\hline $\begin{array}{l}\text { White sauce }+ \text { Hyssopus officinalis } L .+ \text { Ocimum } \\
\text { basilicum L. }+ \text { Dracocephalum moldavica } L .\end{array}$ & 5.0 & 5.0 & 4.3 & 4.8 & 4.775 \\
\hline $\begin{array}{l}\text { White sauce }+ \text { bay leaf }+ \text { black pepper peas }+ \\
\text { ground black pepper }+ \text { greens }+ \text { Hyssopus } \\
\text { officinalis L. Ocimum basilicum L. }+ \\
\text { Dracocephalum moldavica L. }\end{array}$ & 5.0 & 5.0 & 5.0 & 5.0 & 5.000 \\
\hline
\end{tabular}

Sensory evaluation of red main sauce with the addition of spicy-aromatic vegetable raw materials

The addition of spicy-aromatic vegetable raw materials to the red main sauce significantly enriched it and increased the tasting score (Table 6).

Sensory evaluation of red main sauce

Table 6

\begin{tabular}{|c|c|c|c|c|c|}
\hline Compositions & 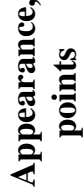 & 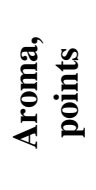 & 产 & 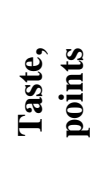 & 灾产 \\
\hline Sauce red (main) on beef broth (control) & 5.0 & 4.2 & 5.0 & 4.0 & 4.550 \\
\hline Sauce red + Ocimum basilicum L. & 5.0 & 5.0 & 5.0 & 5.0 & 5.000 \\
\hline Sauce red + Agastache foeniculum $L$. & 5.0 & 5.0 & 5.0 & 4.8 & 4.950 \\
\hline Sauce red + Hyssopus officinalis $L$. & 5.0 & 5.0 & 5.0 & 4.2 & 4.800 \\
\hline Sauce red + Satureja hortensis L. & 5.0 & 5.0 & 5.0 & 4.7 & 4.925 \\
\hline Sauce red + Dracocephalum moldavica $L$. & 5.0 & 5.0 & 5.0 & 4.5 & 4.875 \\
\hline Sauce red + Glebionis coronaria L. & 5.0 & 5.0 & 5.0 & 4.7 & 4.925 \\
\hline
\end{tabular}

For the production of red main sauce used a hybrid of tomatoes «Maximato $\mathrm{F}_{1}$, which have an increased dry matter content $-5.2 \%$; total sugar $-3.0 \%$; vitamin C content -20.9 $\mathrm{mg} / 100 \mathrm{~g}$; total acidity $-0.51 \%$, which significantly exceeds other tomato hybrids.

To enrich the aroma and taste of the red main sauce, it is recommended to add spicyaromatic herbs, especially Ocimum basilicum L. S.e. $-5,000$ points. 


\section{Sensory evaluation of compotes with addition of spicy-aromatic vegetable raw materials}

Traditionally, the healing drink in Ukraine is dried fruit compote. The aroma and taste of compotes were improved by adding spicy-aromatic vegetable raw materials (Table 7).

\section{Sensory evaluation of dried fruit compotes}

Table 7

\begin{tabular}{|c|c|c|c|c|c|}
\hline Compositions & 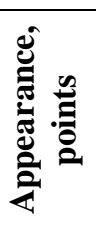 & 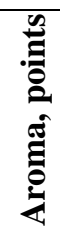 & 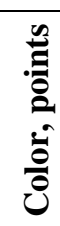 & 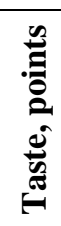 & 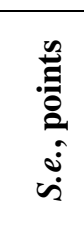 \\
\hline Dried fruit compote (control) & 5.0 & 5.0 & 5.0 & 5.0 & 5.000 \\
\hline Dried fruit compote + Hyssopus officinalis $L$. & 5.0 & 4.9 & 5.0 & 4.9 & 4.950 \\
\hline $\begin{array}{l}\text { Dried fruit compote }+ \text { Dracocephalum moldavica } \\
\text { L. }\end{array}$ & 5.0 & 4.8 & 5.0 & 4.9 & 4.925 \\
\hline Dried fruit compote + Agastache foeniculum $L$. & 5.0 & 5.0 & 5.0 & 5.0 & 5.000 \\
\hline Dried fruit compote + Melissa officinalis $L$. & 5.0 & 4.9 & 5.0 & 4.9 & 4.950 \\
\hline $\begin{array}{l}\text { Dried fruit compote + herbal mixture (Hyssopus } \\
\text { officinalis L., Dracocephalum moldavica L., } \\
\text { Agastache foeniculum L., Melissa officinalis L.) }\end{array}$ & 5.0 & 4.8 & 5.0 & 4.8 & 4.900 \\
\hline
\end{tabular}

The samples with the addition of spicy-aromatic herbs in aroma, color and taste were at the level of control (compote made from dried apples), slightly lower scores on aroma and taste can be considered insignificant compared to the fact that herbs significantly enriched the biochemical composition of the product. The specimen with the addition of Agastache foeniculum L. (S.e. - 5,000 point), which was better than the control, was especially distinguished.

The data obtained are correlated with the basic scientific concepts which are displayed in the works (Buglass et al., 2012; Frolova, Ukrayinets, 2018; Frolova, Korablova, 2016; Gerolis et al., 2017; Grunert et al., 2018; Gullón et al., 2018; Gulua et al., 2018; Imark et al., 2000; Joubert, Beer, 2012; Kamdem et al., 2013; Naithani et al., 2006; Naumenko et al., 2015, 2017; Pyrzynska, Sentkowska, 2019; Ruiz-Ruiz et al., 2020; Sentkowska, Pyrzynska, 2018; Siddiqui et al., 2018; Silka et al., 2016; Steenkamp et al., 2004; Wong et al., 2020), regarding the processes of extracting of plant materials.

Improving restaurant technology (Andreou et al., 2018; Chandrasekara, Shahidi, 2018; Fotakis et al., 2016; Halliwell, Gutteridge, 1990; Iannitti, Palmieri, 2009; Kawa-Rygielska et al., 2019; Kurylo et al. , 2018; Vergun et al., 2018; Vergun et al., 2019) due to the addition of spicy-aromatic raw materials. It allows to increase the antioxidant properties of the product (Breiter et al., 2011; Dube et al., 2017; Herrera et al., 2018; Humia et al., 2020; Keating et al., 2014; Kurylo et al., 2018; Oh et al., 2013; Vergun et al., 2018; Vergun et al., 2019), will help to increase the immunity of the human body, improve the metabolism, positively affect the cardiovascular system, in addition it increases the consumer properties and will allow to reduce the cost of the finished product (Kumar et al., 2018; Peschel et al., 2006; Tan et al., 2020; Wang et al., 2019). 


\section{Conclusions}

1. The expediency of using non-traditional for restaurant technology spicy-aromatic vegetable raw materials in the creation of tea-herbal compositions, sauces of white and red main, compotes, in order to increase the biological value and improve sensory characteristics.

2. Experimental studies show that all aqueous-alcoholic extracts of aromatic origin contain antioxidant systems. It was found that the recovery value of all the tested extracts is positive and ranges from (RE) 120.6 (Agastache foeniculum L.) to 250.2 $\mathrm{mV}$ (Hyssopus officinalis L.).

3. Based on mathematical and statistical analysis, it was found that the infusion temperature $(t)$ has a statistically insignificant effect on physicochemical parameters $\left(p H, E h_{\text {min }}, E h_{a c t}, R E\right)$, which have a statistically insignificant effect on sensory evaluation (S.e.). The range of values with very high correlation $(r=0.9-1.0)$ includes the following indicators: $p H, E h_{\min }, E h_{a c t}, R E$.

4. Improvement of restaurant technology by adding spicy-aromatic raw materials allows to increase the redox properties of the product, increases consumer properties and reduces the cost of the finished product.

5. Compositions of spicy-aromatic vegetable raw materials for restaurant technology in the production of tea-herbal compositions, white and red main sauces, compotes of high biological value and improved sensory characteristics have been studied.

\section{References}

Alaşalvar H., Çam M. (2019), Process for production of ready to drink iced teas from sage (Salvia officinalis L.) and linden (Tilia cordata): pressurized hot water extraction and spray drying, Food Science and Biotechnology, 28(3), pp. 779-785.

Andreou V., Strati I.F., Fotakis C., Liouni M., Sinanoglou V.J. (2018), Herbal distillates: A new era of grape marc distillates with enriched antioxidant profile, Food Chemistry, 253, pp. 171-178.

Bahir V.M. (1999), Sovremennye tehnicheskie jelektrohimicheskie sistemy dlja obezzarazhivanija, ochistki i aktivirovanija vody, VNIIIMT.

Belemets T., Yushchenko N., Lobok O., Radziyevska I., Polonskaya T. (2016), Optimization of composition of blend of natural vegetable oils for the production of milk-containing products, Eastern-European Journal of Enterprise Technologies, 5/11(83), pp. 4-9.

Breiter T., Laue C. Kressel G., Gröll S., Hahn A. (2011), Bioavailability and antioxidant potential of rooibos flavonoids in humans following the consumption of different rooibos formulations, Food Chemistry, 128(215), pp. 338-347.

Buglass A.J., Caven-Quantrill D.J. (2012), Applications of natural ingredients in alcoholic drinks, Natural Food Additives, Ingredients and Flavourings, 16, pp. 358-416.

Chandrasekara A., Shahidi F. (2018), Herbal beverages: Bioactive compounds and their role in disease risk reduction - A review, Journal of Traditional and Complementary Medicine, 8(4), pp. $451-458$.

Dainelli D., Gontard N., Spyropoulos D., Zondervan-van den Beuken E., Tobback P. (2008), Active and intelligent food packaging: Legal aspects and safety concerns, Trends in Food Science \& Technology, 19(1), pp. 103-112.

Damyanova S., Mollova S., Stoyanova A, Gubenia O. (2016), Chemical composition of Salvia officinalis 1. essential oil from Bulgaria, Ukrainian Food Journal, 5(4), pp. 695-700.

Dube P., Meyer S., Marnewick J.L. (2017), Antimicrobial and antioxidant activities of 


\section{- Food Technology —}

different solvent extracts from fermented and green honeybush (Cyclopia intermedia) plant material, South African Journal of Botany, 110, pp. 184-193.

Fotakis C., Tsigrimani D., Tsiaka T., Lantzouraki D.Z., Zoumpoulakis P. (2016), Metabolic and antioxidant profiles of herbal infusions and decoctions, Food Chemistry, 211, pp. 963-971.

Frolova N., Korablova O. (2016), Scientific basis of use of fruits coriandrum sativum L. in food technologies, Potravinarstvo Slovak Journal of Food Sciences, 10(1), pp. 469-474.

Frolova N., Ukrayinets A. (2018), Development of methods of production in natural aromatic production, Ukrainian Food Journal, 7(4), pp. 692-702.

Frolova N., Uktainets A., Korablova O., Voitsekhivskyi V. (2019), Plants of nepeta cat aria var. citriodora beck. and essential oils from them for food industry, Potravinarstvo Slovak Journal of Food Sciences, 13(1), pp. 449-455.

Gerolis L.G.L., Lameiras F.S., Krambrock K., Neves M.J. (2017), Effect of gamma radiation on antioxidant capacity of green tea, yerba mate, and chamomile tea as evaluated by different methods, Radiation Physics and Chemistry, 130, pp. 177-185.

Gnytsevych V., Yudina T., Deinychenko L., Nykyforov R., Nazarenko I. (2018), Survey of characteristics of dairy-protein concentrates in the low-temperature storage process, EasternEuropean Journal of Enterprise Technologies, 1/11(91), pp. 16-22.

Grunert K.G., Hieke S., Juhl H.J. (2018), Consumer wants and use of ingredient and nutrition information for alcoholic drinks: A cross-cultural study in six EU countries, Food Quality and Preference, 63, pp. 107-118.

Gubskyi S., Nikitin S., Evlash V., Niemirich O. (2015), Iodine content determination in dried talli of laminaria by galvanostatic coulometry, Ukrainian Food Journal, 4(2), pp. 320-327.

Gullón B., Eibes G., Moreira M.T., Herrera R., Gullón P. (2018), Yerba mate waste: A sustainable resource of antioxidant compounds, Industrial Crops and Products, 113, pp. 398405 .

Gulua L., Nikolaishvili L., Jgenti M., Turmanidze T., Dzneladze G. (2018), Polyphenol content, anti-lipase and antioxidant activity of teas made in Georgia, Annals of Agrarian Science, 16 (3), pp. 357-361.

Deinychenko L., Deinychenko G., Gnitsevych V., Kravchenko T. (2020), Influence of processing parameters on the techno-functional properties of berry coagulants, Ukrainian Food Journal, 9(1), pp. 74-86.

Halliwell B., Gutteridge J.M.C. (1990), The antioxidants of human extracellular fluids, Archives of Biochemistry and Biophysics, 280, pp. 1-8.

Herrera T., Aguilera Y., Rebollo-Hernanz M., Bravo E., Martín-Cabrejas M.A. (2018), Teas and herbal infusions as sources of melatonin and other bioactive non-nutrient components, $L W T$, 89, pp. 65-73.

Hinkle D.E., Wiersma W., Jurs S.G. (2003), Applied statistics for the behavioral sciences, Boston, Mass: Houghton Mifflin.

Hrabovska O., Pastukh H., Moiseeva V., Miroshnyk V. (2015), Potato pectin: extract methods, physical and chemical properties and structural features, Ukrainian Food Journal, 4(1), pp. 7-13.

Hrabovska O., Pastukh H., Lysyi O., Miroshnyk V., Shtangeeva N. (2018), The use of enzyme preparations for pectin extraction from potato pulp, Ukrainian Food Journal, 7(2), pp. 215-233.

Humia B.V., Santos K.S., Schneider J.K., Leal I.L., Padilha F.F. (2020), Physicochemical and sensory profile of Beauregard sweet potato beer, Food Chemistry, 312, 126087.

Ianchyk M., Niemirich O., Gavrysh A., Yanchyk O. (2016), Study of functional and technological properties of plant powders for use in confectionery industry, Journal of Food Science and Technology-Ukraine, 10(4), pp. 31-36.

Ianchyk M., Niemirich O., Vasheka O., Petrusha O., Pogozhikh N. (2018), Effect of banana powder and butter on the formation of the crystalline phase of sugar fondant, Eastern-European 
Journal of Enterprise Technologies, 4/11(94), pp. 35-41.

Iannitti T., Palmieri B. (2009), Antioxidant therapy effectiveness: an up to date, European Review for Medical and Pharmacological Sciences, 13, pp. 245-278.

Imark C., Kneubühl M., Bodmer S. (2000), Occurrence and activity of natural antioxidants in herbal spirits, Innovative Food Science \& Emerging Technologies, 1 (4), pp. 239-243.

Joubert E., Beer D. (2012), Phenolic content and antioxidant activity of rooibos food ingredient extracts, Journal of Food Composition and Analysis, 27(1), pp. 45-51.

Kamdem J.P., Olalekan E.O., Hassan W., Kade I.J., Rocha J.B.T. (2013), Trichilia catigua (Catuaba) bark extract exerts neuroprotection against oxidative stress induced by different neurotoxic agents in rat hippocampal slices, Industrial Crops and Products, 50, pp. 625-632.

Kawa-Rygielska J., Adamenko K., Kucharska A.Z., Szatkowska K. (2019), Fruit and herbal meads - Chemical composition and antioxidant properties, Food Chemistry, 283, pp. 19-27.

Keating L., Hayes J., Moane S., Lehane M., Furey A. The effect of simulated gastrointestinal conditions on the antioxidant activity of herbal preparations made from native Irish hawthorn. Journal of Herbal Medicine. 4(3), 2014. pp. 127-133.

Kochubei-Lytvynenko O., Marynin A., Yushchenko N., Kuzmyk U., Lazarenko M. (2017), Stude of the state of moisture in the curd paste with sumach extract and the addition of buckwheat groats, Eastern-European Journal of Enterprise Technologies, 6(90), pp. 22-26.

Kumar V., Kushwaha R., Goyal A., Tanwar B., Kaur J. (2018), Process optimization for the preparation of antioxidant rich ginger candy using beetroot pomace extract, Food Chemistry, 245, pp. 168-177.

Kurylo V.L., Rakhmetov D.B., Kulyk M.I. (2018), Biological features and potential of yield of energy crops of the thin-skinned family in the conditions of Ukraine, Bulletin of Poltava State Agrarian Academy, 1, pp. 11-17.

Kuzmin O., Kucherenko V., Sylka I., Isaienko V., Furmanova Y., Pavliuchenko E., Hubenia V. (2020), Antioxidant capacity of alcoholic beverages based on infusions from non-traditional spicy-aromatic vegetable raw materials, Ukrainian Food Journal, 9 (2), pp. 404-424.

Kuzmin O., Kovalchuk Y., Velychko V., Romanchenko N. (2016), Improvement technologies of aqueous-alcoholic infusions for the production of syrups, Ukrainian Journal of Food Science, 4(2), pp. 258-275.

Mayor L., Sereno A. M. (2004), Modelling shrinkage during convective drying of food materials: a review, J Food Eng., 61(3), pp. 373-386.

Merwe J.D., Beer D., Swanevelder S., Joubert E., Gelderblom W.C.A. (2017), Dietary exposure to honeybush (Cyclopia) polyphenol-enriched extracts altered redox status and expression of oxidative stress and antioxidant defense-related genes in rat liver, South African Journal of Botany, 110, pp. 230-239.

Mujumdar A.S., Law C.L. (2010), Dry Technol: Trends and applications in postharvest processing, Food Bioprocess Tech., 3(6), pp. 843-852.

Naithani V., Nair S., Kakkar P. (2006), Decline in antioxidant capacity of Indian herbal teas during storage and its relation to phenolic content, Food Research International, 39 (2), pp. 176181.

Naumenko K., Petrusha O., Frolova N., Fedorenko O. (2015), Quality assessment of extracts from unconventional plant raw materials, Eastern-European Journal of Enterprise Technologies, 4(10), pp. 49-54.

Naumenko K., Frolova N., Petrusha O., Chepel N. (2017), The use of gas chromatography in determining the sorption capacity of the adsorbent, Eastern European Journal of Enterprise Technologies, 1/10(85), pp. 70-74.

Nicoli M.C., Toniolo R., Anese M. (2004), Relationship between redox potential and chainbreaking activity of model systems and foods, Food Chemistry, 88(1), pp. 79-83.

Niemirich A., Petrusha O., Yasyuchenko A., Drozd D. (2015), Research of reducing and emulsifying abilities of vegetable and fruit powder, Eastern-European Journal of Enterprise 


\section{Food Technology}

Technologies, 3/10 (75), pp. 26-30.

Niemirich A., Tarasenko T., Petrusha O., Vasheka O., Havrysh A., Zayets V. (2015), Effect of vegetable powder on the properties of pancake batter and semifinished products, EasternEuropean Journal of Enterprise Technologies, 2/10 (74), pp. 45-49.

Niemirich A., Petrusha O., Vasheka O., Trofymchuk L., Myndrul N. (2016), Exploring the color of plant powders using computer colorimetry, Eastern-European Journal of Enterprise Technologies, 4/11 (82), pp. 15-20.

Niemirich O., Pogozhich M., Petrusha O., Havrysh A., Vasheka O. (2017), Restoring and emulsifying properties of the dried meat semi-finished product, Ukrainian Food Journal, 6(2), pp. 302-314.

Oh J., Jo H., Cho A.R., Kim S.J., Han J. (2013), Antioxidant and antimicrobial activities of various leafy herbal teas, Food Control, 31(2), pp. 403-409.

Pavlyuk R., Pogarskaya V., Cherevko O., Pavliuk V., Radchenko L., Dudnyk E., Radchenko A., Kolomiets T. (2018), Studying the complex of biologically active substances in spicy vegetables and designing the nanotechnologies for cryosupplements and nanoproducts with health benefits, Eastern-European Journal of Enterprise Technologies, 4/11(94), pp. 6-14.

Peschel W., Sánchez-Rabaneda F., Diekmann W., Plescher A., Gartzía I., Jiménez D., Lamuela-Raventós R., Buxaderas S., Codina C. (2006), An industrial approach in the search of natural antioxidants from vegetable and fruit wastes, Food Chemistry, 97(1), pp. 137-150.

Priecina L., Karklina D., Kince T. (2018), The impact of steam-blanching and dehydration on phenolic, organic acid composition, and total carotenoids in celery roots, Innovative Food Science \& Emerging Technologies, 49, pp. 192-201.

Priluckij V.I. (1997), Okislitel'no-vosstanovitel'nyj potencial dlja harakteristiki protivokislitel'noj aktivnosti razlichnyh napitkov $i$ vitaminnyh komponentov, Jelektrohim. aktivacija v medicine, sel. hozjajstve, prom-sti: I Mezhdunar. Simpozium.

Prévost H., Brillet-Viel A. (2014), Ecology of bacteria and fungi in foods, Influence of Redox Potential, Encyclopedia of Food Microbiology (Second Edition), pp. 595-601.

Pyrzynska K., Sentkowska A. (2019), Herbal Beverages as a Source of Antioxidant Phenolics, Natural Beverages, 5, pp. 125-142.

Rakhmetov D.B. (2011), Teoretychni ta prykladni aspekty introduktsiyi roslyn v Ukrayini, Kiev: Ahrar Media Crup.

Ruiz-Ruiz J.C., Aldana G.C.E, Cruz A.I.C., Segura-Campos M.R. (2020), Antioxidant Activity of Polyphenols Extracted From Hop Used in Craft Beer, Biotechnological Progress and Beverage Consumption, 9, pp. 283-310.

Ruan J., Cai Q., Jin S. (2021), Impact of COVID-19 and Nationwide Lockdowns on Vegetable Prices: Evidence from Wholesale Markets in China, American Journal of Agricultural Economics, Available at: https://onlinelibrary.wiley.com/doi/10.1111/ajae.12211

Sentkowska A., Pyrzynska K. (2018), Investigation of antioxidant interaction between Green tea polyphenols and acetaminophen using isobolographic analysis, Journal of Pharmaceutical and Biomedical Analysis, 15910, pp. 393-397.

Shendrik T., Levandovskyi L., Kuts A., Prybylskyi V., Karputina M. (2019), Correlation between the quality indicators of activated coal in vodka technology, Ukrainian Journal of Food Science, 7(1), pp. 33-48.

Siddiqui N.A., Al-Yousef H.M., Alhowiriny T.A., Alam P., Abdallah R.H. (2018), Concurrent analysis of bioactive triterpenes oleanolic acid and $\beta$-amyrin in antioxidant active fractions of Hibiscus calyphyllus, Hibiscus deflersii and Hibiscus micranthus grown in Saudi Arabia by applying validated HPTLC method, Saudi Pharmaceutical Journal, 26, pp. 266-273.

Silka I., Frolova N., Huts V. (2016), Kinetic model of the quality change of modern foodstuffs, Food Science and Technology, 10(1), pp. 11-15.

Steenkamp V., Fernandes A.C., Rensburg C.E.J., Jäger A.K. (2004), Antioxidant scavenging potential of South African export herbal teas, South African Journal of Botany, 70(4), 
pp. 660-663.

Swasdisevi T., Devahastin S., Sa-Adchom P., Soponronnarit S. (2009), Mathematical modeling of combined far-infrared and vacuum drying banana slice, J Food Eng, 92(1), pp. 100 106.

Sylchuk T., Zuiko V., Tsyrulnikova V. (2016), Investigation of changes in physical properties of rye-wheat dough using acidulants, Food Science and Technology, 10(1), pp. 4953.

Sylchuk T., Bilyk O., Kovbasa V., Zuiko V. (2017), Investigation of the effect of multicomponent acidulants on the preservation of freshness and aroma of rye-wheat bread, Eastern-european journal of enterprise technologies, 5/11(89), pp. 4-9.

Tan L., Nuffer H., Feng J., Kwan S.H., Chen H., Tong X., Kong L. (2020), Antioxidant properties and sensory evaluation of microgreens from commercial and local farms, Food Science and Human Wellness, 9(1), pp. 45-51.

Tülek Z., Alaşalvar H., Başyiğit B., Berktas S., Salum P., Erbay Z., Telci I., Çam M. (2020), Extraction optimization and microencapsulation of phenolic antioxidant compounds from lemon balm (Melissa officinalis L.): Instant soluble tea production, Journal of Food Processing and Preservation, Available at: https://ifst.onlinelibrary.wiley.com/doi/10.1111/jfpp.14995

Vergun O., Kačaniova M., Rakhmetov D., Shymanska O., Bondarchuk O., Brindza J., Ivanišová E. (2018), Antioxidant and antimicrobial activity of Bunias orientalis L. and Scorzonera hispanica L. ethanol extracts, Agrobiodiversity for Improving Nutrition, Health and Life Quality, 2, pp. 29-38.

Vergun O., Svydenko L., Grygorieva O., Shymanska O., Rakhmetov D., Brindza J., Ivanišová E. (2019), Antioxidant capacity of plant raw material of Scutellaria baicalensis Georgi, Potravinarstvo Slovak Journal of Food Science, 13(1), pp. 614-621.

Wang J., Zhang M., Devahastin S., Liu Y. (2019), Influence of low-temperature ball milling time on physicochemical properties, flavor, bioactive compounds contents and antioxidant activity of horseradish powder, Advanced Powder Technology, 31(3), pp. 914-921.

Wong F.C., Xiao J., Wang S., Ee K.Y., Chai T.T. (2020), Advances on the antioxidant peptides from edible plant sources, Trends in Food Science \& Technology, 99, pp. 44-57. 